\title{
Community Ecology, Macro-Ecological Patterns, and Conservation of Tropical Beetles: An Introduction
}

\author{
Luca Luiselli $1,2,3, *$ (D) and Giovanni Amori ${ }^{4}$ (D) \\ 1 Institute for Development, Ecology, Conservation and Cooperation, 00144 Rome, Italy \\ 2 Department of Applied and Environmental Biology, Rivers State University of Science and Technology, \\ Port Harcourt P.M.B. 5080, Nigeria \\ 3 Department of Zoology, University of Lomé, Lomé 01 BP 1515, Togo \\ 4 National Research Council (CNR), Institute of Research on Terrestrial Ecosystems, 00185 Rome, Italy; \\ giovanni.amori@cnr.it \\ * Correspondence: 1.luiselli@ideccngo.org
}

check for updates

Citation: Luiselli, L.; Amori, G. Community Ecology,

Macro-Ecological Patterns, and

Conservation of Tropical Beetles: An Introduction. Diversity 2021, 13, 406. https://doi.org/10.3390/d13090406

Received: 14 August 2021

Accepted: 23 August 2021

Published: 26 August 2021

Publisher's Note: MDPI stays neutral with regard to jurisdictional claims in published maps and institutional affiliations.

Copyright: (c) 2021 by the authors. Licensee MDPI, Basel, Switzerland. This article is an open access article distributed under the terms and conditions of the Creative Commons Attribution (CC BY) license (https:// creativecommons.org/licenses/by/ $4.0 /)$.
Keywords: Coleoptera; tropical regions; ecology; synecology; biogeography; applied entomology; conservation biology

Tropical regions host a large variety of animal species, representing the richest concentrations of biological diversity across the Earth. For instance, it is estimated that a single tropical biome (i.e., tropical forest) contains more than half the species of plants, insects (e.g., ants, termites, butterflies, and beetles), amphibians, birds, mammals and other organism groups on Earth [1]. In addition, most of the 36 "conservation hotspots" (which are defined as sites containing at least 1500 endemic vascular plants, at least $0.5 \%$ of all plant species worldwide and $30 \%$ or less of its original natural vegetation) are located in the tropics (for instance, Madagascar, Tropical Andes, West African forests, Indo-Burma, etc.) [2].

Macroecological patterns are also peculiar in the tropics, where the species' distribution ranges tend to be smaller than in temperate regions (according to the acclaimed Rapoport's rule [3]) due to a plethora of reasons including a generally intensified interspecific competition and niche packing [4]. Thus, assembly rules and community structures are generally more complicated in the tropics than in temperate regions.

Tropical regions are also particularly vulnerable with respected to conservation due to: (i) a plethora of local factors (deforestation, pollution, development initiatives, overhunting) exacerbated by the diffuse poverty of many countries situated in the tropics [1], and (ii) global change reasons [5]. In this latter case, some biomes (for instance, tropical forests) tend to shrink, whereas others (deserts, subdeserts, arid savannahs and grasslands) tend to expand due to the effects of desertification that are increasing throughout vast regions of the tropics [6].

Insects represent the great majority of animal species throughout the world, and Coleoptera (=beetles) constitute one of the largest orders of living insects (well over 350,000 species overall, with many more certainly still to be described, spread in over 210 families) [7]. Unsurprisingly, the greatest concentrations of insect species also occur in the tropics, and especially in rainforests, due to the highest diversity of host plants available [8]. In addition, tropical regions include, among the others, the largest beetle species in the world, other than several of the most bizarre and ecologically lesser-known taxa (Figure 1). However, several of these "impressive" species are subjected to a vigorous commercial trade which may threaten the long-term survival of their populations, thus making the study of tropical beetles important from a conservation point of view as well. For instance, a long-term decline of particularly attractive (and commercially valuable) color morphs in wild populations of large-sized tropical beetles has been observed [9]. 
a)

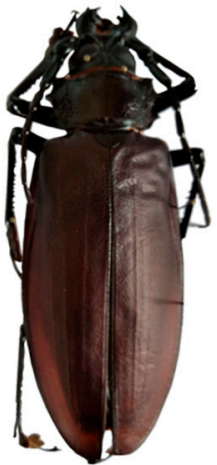

C)

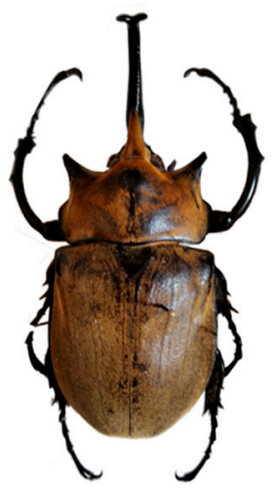

b)

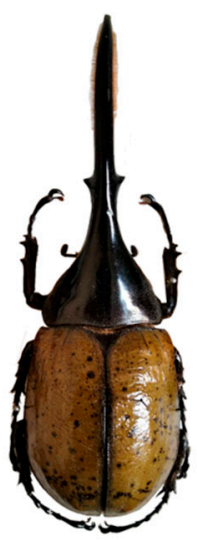

d)

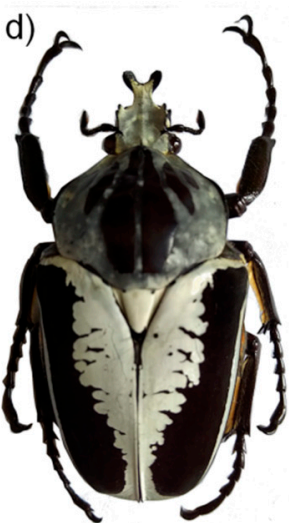

Figure 1. The largest beetle species in the world are living in tropical forests. In this plate: Titanus giganteus from French Guyana (a), Dynastes hercules from Colombia (b), Megasoma elephas from Mexico (c), and Goliathus regius from Ghana (d). All specimens are currently stored in the "Luiselli Entomological collection", Rome, Italy. Photos: L. Luiselli.

Last, but not least, tropical beetles may be eaten by rural human populations (especially during periods with shortness of available protein food (dry season) [10]), and they may also represent serious pests for crops of crucial human relevance [11]. Interestingly, there are cases in which the same species may be at the same time an important food resource for rural human populations (either as a larva or as an adult) but also a serious threat for their crops and economy (as in the case of the dynastine Augosoma centaurus) [10,11]. These species should be studied for the sake of a better understanding of the applied entomological aspects and management of the fragile ecosystems of tropical regions.

Therefore, borrowing the terminology used in statistics from analysis of variance, the "interaction term" between "tropics" and "beetles" certainly represents a noteworthy model for studies on life-history evolution, ecology, biogeography, and conservation. Nonetheless, tropical beetles and their communities are: (i) generally little known in ecological terms, and (ii) strongly overlooked by major conservation organizations and, in most cases, not even considered by the IUCN Red List [12]. However, if we run in Google Scholar (on 12 August 2021) the words "tropical beetles taxonomy", a total of about 50,800 results were obtained, whereas 184,000 results were found with "tropical beetles' ecology" and 94,500 with "tropical beetles conservation". These scores clearly show that the scientific interest is still strong on the natural history of these insects, although with evident geographic biases among tropical regions: for instance, the Google Scholar results for "African beetles" were 90,200, whereas those for Asian beetles were 91,400, and those for South American beetles were 175,000 (compared to 222,000 results for North American beetles and 210,000 for European beetles).

Based on the above-mentioned considerations, it is urgent to provide the scientific community with synthetic studies collating aspects of community ecology, macroecology, applied entomology, and conservation for beetle assemblages in various tropical biomes 
and ecosystems. It would be particularly interesting, for instance, to see published studies detailing the variation patterns of community assembly rules of tropical beetles at different spatial scales (from the continental to the micro-habitat scale). A study of this kind has recently been published on an African family of freshwater turtles [13], and this study may well serve as an example for similar studies on tropical coleopters as well. We would therefore urge tropical ecologists and entomologists to coagulate their efforts in order to produce a series of synoptic studies that may form the basis for further in-depth experimental research on the above-mentioned issues. The present contribution would serve as a plea for all interested scientists to contribute to further studies on tropical beetle community ecology and conservation.

Author Contributions: L.L. and G.A., writing-original draft preparation, review and editing. Both authors have read and agreed to the published version of the manuscript.

Funding: This research received no external funding.

Institutional Review Board Statement: Not applicable.

Data Availability Statement: Not applicable.

Conflicts of Interest: The authors declare no conflict of interest.

\section{References}

1. Santos, J.C.; Almeida-Cortez, J. Origin and maintenance of tropical biodiversity. In Tropical Biology and Conservation Management; Encyclopedia of Life Support Systems EOLSS: Oxford, UK, 2009; Volume V.

2. Myers, N.; Mittermeier, R.A.; Mittermeier, C.G.; da Fonseca, G.A.B.; Kent, J. Biodiversity hotspots for conservation priorities. Nature 2000, 403, 853-858. [CrossRef] [PubMed]

3. Rapoport, E. Aerography: Geographical Strategies of Species; Pergamon Press: New York, NY, USA, 1982.

4. Pianka, E.R. Latitudinal gradients in species diversity: A review of the concepts. Am. Nat. 1966, 100, 33-46. [CrossRef]

5. Scholes, R.J.; Van Breemen, N. The effects of global change on tropical ecosystems. Geoderma 1997, 79, 9-24. [CrossRef]

6. Luiselli, L.; Benansio, J.S.; Demaya, G.S.; Dendi, D.; Amori, G. Climate Change Intensifies Human-Crocodile Conflicts in War-Torn South Sudan. Science 2021. Available online: https:/ / science.sciencemag.org/content/373/6554/484/tab-e-letters (accessed on 25 August 2021).

7. Bouchard, P.; Bousquet, Y.; Davies, A.; Alonso-Zarazaga, M.; Lawrence, J.; Lyal, C.; Newton, A.; Reid, C.; Schmitt, M.; Ślipiński, A.; et al. Family-group names in Coleoptera (Insecta). ZooKeys 2011, 88, 1-972. [CrossRef] [PubMed]

8. Novotny, V.; Drozd, P.; Miller, S.E.; Kulfan, M.; Janda, M.; Basset, Y.; Weiblen, G.D. Why are there so many species of herbivorous insects in tropical rainforests? Nature 2006, 313, 1115-1118. [CrossRef] [PubMed]

9. Dendi, D.; Ajong, S.J.; Amori, G.; Luiselli, L. Decline of the commercially attractive white morph in Goliath beetle polymorphic populations from West Africa. Diversity 2021, 13, 388. [CrossRef]

10. Muafor, F.J.; Levang, P.; Le Gall, P. A crispy delicacy: Augosoma beetle as alternative source of protein in East Cameroon. Int. J. Biodivers. 2014, 2014, 1-7. [CrossRef]

11. Venard-Combes, P.; Mariau, D. Augosoma centaurus, Fabricius (Coleoptera Scarabeidae), a serious pest of coconut in Africa. Descriptions, biology, method of control. Oléagineux 1983, 38, 651-657.

12. IUCN. The IUCN Red List of Endangered Species. Available online: www.iucnredlist.org (accessed on 11 August 2021).

13. Luiselli, L.; Di Vittorio, M.; Rhodin, A.G.J.; Iverson, J. Variation of community assembly rules of a whole turtle family (Pelomedusidae) from continental to local scales in Africa. Ecol. Res. 2021. [CrossRef] 